\title{
RELEVANCE AND PERSPECTIVES OF EXPERIMENTAL WOUND MODELS IN WOUND HEALING RESEARCH
}

\author{
SANTRAM LODHI, GAUTAM P VADNERE*
}

Department of Pharmacognosy, Smt. Sharadchandrika Suresh Patil College of Pharmacy, Chopda, Jalgaon - 425 107, Maharashtra, India. Email: gautamvadnere31@rediffmail.com

Received: 04 March 2017, Revised and Accepted: 13 April 2017

\section{ABSTRACT}

The wound healing process consists of four highly integrated and overlapping phases: Hemostasis, inflammation, proliferation, and tissue remodeling. These phases and their biophysiological functions must occur in the proper sequence, at a specific time and continue for a specific duration at an optimal intensity. There are many factors that can affect wound healing which interferes with one or more phases in this process, thus causing improper or impaired tissue repair. This review was aimed to collect data and made a critical analysis. This will provide concise information regarding different models and parameters used for wound healing study. The data related to different wound models are collected using popular search engines as well as relevant science search engines and database including Google Scholar, Science Direct, and PubMed. A new drug substance can be evaluated for wound healing activity using different in vitro models such as cell culture, chick chorioallantoic membrane model, tube formation on metrigel and capillary growth model. The in vivo wound models such as incision, excision, dead space, burn wound, ischemic wound, and diabetic wound models are frequently used. Each model has specific importance. The limitations and advantages of each are described in this review. Although animal wound repair is an imperfect reflection of human wound healing and its clinical challenges, these models can be fundamental tools for the development of new approaches to rational wound therapy.

Keywords: Wound healing, Animal models, Cell culture, Burn, Ischemic wound, Diabetic.

(C) 2017 The Authors. Published by Innovare Academic Sciences Pvt Ltd. This is an open access article under the CC BY license (http://creativecommons. org/licenses/by/4. 0/) DOI: http://dx.doi.org/10.22159/ajpcr.2017.v10i7.18276

\section{INTRODUCTION}

Wound can be defined as any process which leads to the disruption of the normal architecture of a tissue. They may be closed or open, e.g. abrasions, lacerations, avulsions, ballistic and excised, or surgical wounds. Open wounds are by for the most common and are characterized by a break in the skin. Wounds may be classified according to the number of skin layer affected. Damage limited to the epithelial tissue along (epidermis) is regarded as superficial wound, which will heal rapidly by regeneration of epithelial cells [1]. A partial thickness wound involves the deeper dermal layer and includes blood vessel damage. A full thickness wound affects the subcutaneous fat layer and beyond. Its healing requires the synthesis of new connective tissue, and it takes the larger time to heal because it contracts whereas partial thickness wound do not [2]

Healing restores the cellular and anatomic continuity of an organism. It minimizes tissue damage, debris nonviable tissue, maximizes tissue perfusion and oxygenation, proper nutrition provides moist wound healing environment. Major events in the wound healing include inflammation, proliferation, and migration of connective tissue cells production of extracellular matrix including collagen synthesis, epithelial cell migration and proliferation leading to reepithelialization and endothelial cell migration and proliferation leading to neovascularization of the wounded tissue [3]. Healing of a wound can be divided into several stages: The inflammatory phase includes alteration of capillary permeability, transudation, and cellular migration, followed by a proliferative phase which requires a proliferation of fibroblasts, endothelial cells and epithelial cells in the injured area. Finally, there is the remolding phase in which cell production is balanced by cell death, collagen production by degradation and absorption and capillary formation by capillary obliteration. A plethora of cytokines attractant, proteolytic enzymes, fibrin degradation factors, growth factors matrix proteins prostaglandins kinins, autacoids such as histamine, serotonin, and other factors such as oxygen free radicals, nitric oxide, and various trace elements take part in wound healing [4].

To demonstrate a pharmacological effect, nothing can replace observation of animal models, but as they are expensive and often difficult to interpret, simpler tests are used. These tests require less effort and also make possible a better understanding of the mechanisms of action of substances being tested. Non-animal models are becoming smaller and smaller while still remaining representative of a living organism [5]. The advantages of an in vivo model in wound healing research are that the wounded tissue is similar to wound found in clinical practice and in the case of skin wounds, can be made in human subjects. The disadvantages are that direct examination of single tissue components is difficult, and in the case of human skin wounds, only small, clean wounds can be produced, and even this may be an ethical problem [6]. An experimental animal model, therefore, can be defined as a living organism with an intensified, naturally acquired or induced a pathological process that, in one or more respects to closely resembles the same phenomenon in man. This review focus on the different wound models used for evaluation of a drug substance for wound healing activity.

\section{MECHANISM OF WOUND HEALING}

\section{Epidermal wound healing}

In an epidermal wound, central portion of wound may extend to the dermis while the edge of usually involves only slight damage to superficial epidermal cells. Epidermal wound is an abrasion and also it is a first-degree or second-degree burn. In response to injury, basal epidermal cells in wound area, break their contact with basement membrane and then enlarge migrate as a sheet across the wound until advancing cell from opposite sides of the wound meet. When epidermal cells encounter each other, their continue migration is stopped by contact inhibition. Contact inhibition appears to occur only among like cells (epidermal cells) and stops when it is finally in contact on 
all sides with other epidermal cells. Simultaneous with migration of some basal epidermal cells, stationary basal stem cells divide to replace the migrated ones and continue this until the wound is resurfaced to normal status. Following this, the migrated cells themselves divide to form new strata, thus thickening the new epidermis (Fig. 1) [7].

\section{Deep wound healing}

If an injury extends to the epidermis, the repair process is more complex and scar formation results. This type of wound healing is known as deep wound healing. The first step in the deep wound healing involves inflammation, a vascular and cellular response that serves to dispose of microbes and foreign materials. During the inflammatory phase, a blood clots form in the wound and loosely units the wound edges. Vasodilatation and increase permeability of blood vessels enhance delivery of white blood cells such as neutrophils and monocytes (macrophages) that phagocytes microbes and mesenchymal cells, which develops in the fibroblasts. In the second phase that is a migratory phase, the clot becomes a scab, and epithelial cells migrate beneath the scab to bridge the wound. Fibroblasts migrate along fibrin threads and begin synthesizing scar tissue (collagen fibers and glycoprotein), and damaged blood vessels begin to redrew. During this phase tissue, finally, the wound is called granulation tissue. The third phase is a proliferative phase which is characterized by extensive growth of epithelial cells beneath the scab, deposition of collagen fibers by fibroblasts and continue growth of blood vessels. The final phase is the maturation phase, the scab sloughs off once the epidermis is restored to normal thickness. Collagen fibers become more organized, fibroblasts decrease in number, and the blood vessels are restored to normal (Fig. 2) [7].

\section{WOUND HEALING MODELS}

The wound healing is a complex dynamic process, which is influenced by many externally introduced factors and compounds. To obtain a better understanding of the complexity of these processes, research is essential. Wound healing research has been categorized in basic experimental and clinical human research. There are however a few experimental models that are applicable too. Experimental research is fundamental for development in clinical research, because clinical research studies are normally based on results from experimental research [8].

The wounds are heterogeneous, they may be big, small, open, closed, deep, superficial, and consists of different types of tissue, can have different etiologies, and healing may to a certain degree be based on different mechanisms - Epithelialization, contraction, collagen

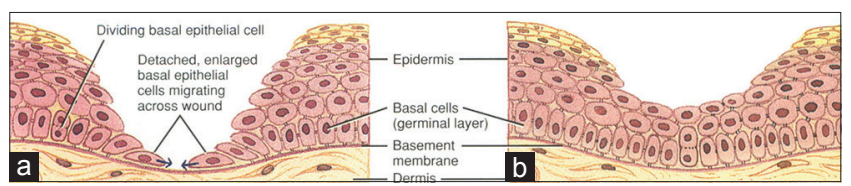

Fig. 1: Epidermal wound healing: (a) Division of basal cells are migrated, (b) resurfacing of wound

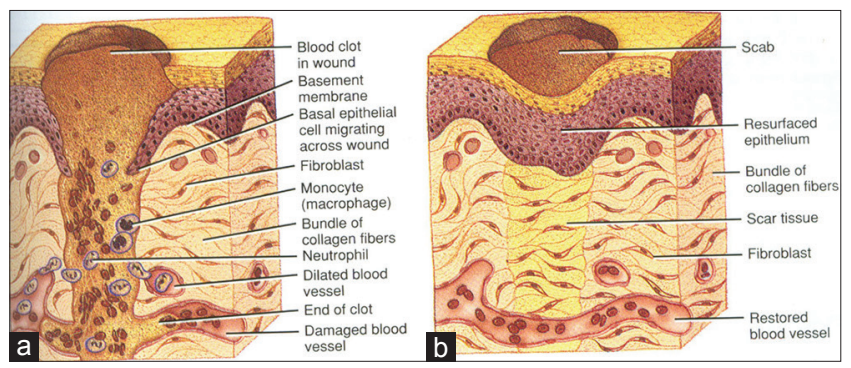

Fig. 2: Deep wound healing: (a) Inflammatory phase, (b) maturation phase production, etc. The interaction of these entire elements makes difficult to wound. However, if each component can be isolated it may be possible to investigate the specific influence of each of these components. To attain this goal, experimental research studies are performed. This can only be achieved if the wound formation and healing circumstances are as similar, comparable and standardized as possible [9].

An experimental animal model, therefore, can be defined as a living organism with an intensified, naturally acquired or induced pathological process that, in one or more respects, closely resembles heal the same phenomenon in man. An experimental human model is a wound healing condition in human allowing standardized measurement of specific components or compounds.

The choice for type of wound healing model depends not only on the problem itself but also on same important practical factors such as the space and physical facilities required for animal studies, laboratory facilities, technical expertise, financial resources, time ethical and legal factors [6].

The models available can be divided into in vitro and in vivo models. Each of these groups can be further subdivided into different types of models [3] gives wound models for the study of wound healing mechanism of an agent.

\section{In vitro wound models}

1. Cell culture

2. Angiogenesis

- Chick chorioallantoic membrane model (CAM)

- Tube formation on metrigel

- Capillary growth in the mammalian cornea.

\section{In vivo models}

1. Excision wound model

2. Incision wound model

3. Sponge matrix model

4. Burn wound model: Partial thickness burn and full thickness burn

5. Diabetic animal wound model

6. Ischemic wound model.

Jaffrey (2001) reported different experimental wound models [10] for the study of wound healing activity are as:

1. Acute wound model: (a) Incision wounds, (b) excision wounds, and (c) dead space model

2. Impaired wound healing model

3. Chronic wound model.

Here in this review article, we are discussing about the method of different wound models and different parameters used to evaluate healing activity.

\section{TYPES OF WOUND HEALING MODELS}

Mainly two types, in vitro and in vivo models are available for evaluation for wound healing activity of an agent. Some of these most frequently used wound models are given below:

\section{In vivo wound models}

In vivo models relate to healing of tissue and organs and can involve both animal human models. The advantages of an in vivo model are wound healing research are that the wounded tissue is similar to wound found in clinical practice, and in the case of skin wounds, can be made in human subjects. The disadvantages are that direct examination of single tissue components is difficult and in the case of human skin wounds, only small, clean wound can be produced, and even this may be an ethical problem. To investigate the efficacy of a therapeutic compound different, parameters such as biochemical and biomechanical studies of the healing tissue, observation of healing macroscopically, measurement of healing markers, cellular response, and the immunological responses [6] 


\section{Incision wound model}

It also represents surgical incision wound model. This model used for measurement of tensile strength after healing of a wound [11]. Two paravertebral or long incisions are made through the skin and cutaneous muscles at a distance of about $1.5 \mathrm{~cm}$ from the midline on each side of the depilated back of the rat. After incision made, the parted skin is kept together and stitched tightly with continuous black silk at $0.5 \mathrm{~cm}$ intervals; surgical thread (No. 000) and a curved needle (No. 11) is used for stitching. When the wounds are cured thoroughly, the sutures are removed, and tensile strength of the healed wound is measured by a Tensiometer. Mean tensile strength of two paravertebral incisions on both sides of animal is noted.

\section{Excision wound model}

It is an open type of wound which is used to study of scar area. An excision wound is induced by excising the skin of impressed area to full thickness to obtain a wound area of about $500 \mathrm{~mm}^{2}$ in anesthetized rat. The wound is left open to environment and these rats are divided into different groups as required. The number of days required for falling of the scar without any residual is known as period of epithelialization. The wound contraction is calculated as the percentage reduction in wound area. The scar shape and area are traced and measured planimetrically [12].

\section{Dead space wound}

This model is used for the study of physical change in granuloma tissue. Dead space wound is created after light ether anesthesia, by implantation of two sterile polypropylene tubes, one on either side, in the lumbar region on the dorsal surface of each animal. On the $10^{\text {th }}$ post wounding day, granuloma tissue formed on implanted tube is dissected out carefully. Granuloma tissue from one tube is kept (at $60^{\circ} \mathrm{C}$ ) for estimation of biochemical parameters. Other tube is used for determination of tensile strength after which it is dried in an oven at $60^{\circ} \mathrm{C}$ for $24 \mathrm{hrs}$ and noted dry weight. The other part of the tissue is kept in $10 \%$ formalin solution for histopathological studies $[13,14]$.

\section{Burn wound model}

\section{Controlled partial skin thickness burn wound}

Partial skin thickness burn wound produced using a round aluminum stamp with a contact area of $4 \mathrm{~cm}^{2}$, weight $85 \mathrm{~g}$, is heated up to $80^{\circ} \mathrm{C}$ and applied for 14 seconds without additional pressure on the depilated dorsal skin of animal. The depth of lesion is investigated by Hematoxylin and eosin (HE) stained paraffin sections. The border of the necrotic zone is found in the central third of the dermis in $80 \%$ of cases, and in the control two quarters in $100 \%$.

The thickness of the skin depends on the stage of hair growth cycle. We, therefore, estimated the hair growth pattern before inflicting burns $[15,16]$.

\section{Full thickness burn wound model}

Full thickness burn injury is induced in all rats according to the methods of Walker and Yalcin $[17,18]$. In this method, rats are anesthetized, and hair on the back of each rat is removed with an electric clipper. The dorsal skin surface is exposed to $95^{\circ} \mathrm{C}$ water for 10 seconds through a template designed to produce a third-degree burn that covered approximately $30 \%$ of the total body surface area. Immediately after the burn injury, $5 \mathrm{ml}$ of physiologic saline is administered intraperitoneal to each rat for fluid resuscitation [19].

\section{Diabetic animal wound model}

Diabetes has a major role in delay of healing, so this model is also known as chronic wound model. Diabetic animals are made by being given a single injection of hyperglycemic drug (streptozotocin/alloxan) prepared in citrate buffer $(0.1 \mathrm{M} \mathrm{pH} 4.5)$ (50 mg/kg) intraperitoneal after overnight fasting. Blood is drowning from the orbital plexus $24 \mathrm{hrs}$ after the injection, and the glucose level is estimated using a glucometer. Circular wound of $8 \mathrm{~mm}$ made on pre-shaved, sterile (with $70 \%$ alcohol) dorsal surface of the animal with the help of a biopsy punch. In the diabetic wound model test drug is applied topically or administered with a suitable concentration range. Blood glucose levels are estimated at the time of creation of the wounds as well as at excision of wounds to check whether the test drug has any antidiabetic activity [20].

\section{Ischemic wound model}

Ischemia is a condition of abnormally low concentration of oxygen in tissue, frequently caused by the poor blood supply. Ischemia is a major contributing to delayed healing (or non-healing) of wounds. There are two models of ischemic skin wound healing have been developed in the rat using single pedicle or bipedicle dorsal skin flaps [21]. These models used to stimulate many of the molecular abnormalities that characterize by ischemic human, increased levels of inflammatory cytokines, metalloproteinase, and elevated proteases. The single pedicle skin flap model produces more severe tissue ischemia that eventually leads to necrosis of the distal segment of the flap.

The bipedicle skin flap model produces moderate transients ischemic that causes delayed healing of full-thickness skin excision wound. Reduced levels of growth factors are found in chronic wound environments. These growth factors, including the transforming growth factor beta family (TGF- $\beta$ ), are necessary to stimulate mitosis of cells involved in wound healing process by reducing the nutrient levels to cells that are responsible for remodeling the wound.

\section{Single pedicle flap model}

A rostral-based single pedicle skin flap measuring $3 \mathrm{~cm} \times 11.5 \mathrm{~cm}$ and extending from the angle of the scapula to the top of the iliac crest is raised on rats. The incision is then closed using stainless steel wound clips, and the flap is marked into three equal regions as proximal, median, and distal with respect to the flap base. After the application of healing drug sample flaps is placed in position and rats are ministered daily for wound complication.

\section{Bipedicle flap model}

In this model, full thickness wounds are created in normal and ischemic rat skin. The animals are weighing and assigned in two groups normal and ischemic wound group containing each 10 rats. The rats are anesthetized and the backs are trimmed with clippers. A flap template positioned and skin is marked using six uniform holes arranged in pairs at $2.6,5.2$, and $7.8 \mathrm{~cm}$ from the end of the template and $3 \mathrm{~mm}$ from each edge. Under aseptic conditions, a pair of full thickness wounds is created using a $6 \mathrm{~mm}$ skin biopsy punch in an electric drill and then skin punch biopsies are frozen immediately in liquid nitrogen and stored at $8^{\circ} \mathrm{C}$ for subsequent analysis. Two parallel incisions expanding through the panniculus carnosus are making only in ischemic group of rats along the long side of the template. The skin flaps then elevated deep to the panniculus carnosus muscle. The skin flaps are repositioned and resutured. Rats are then returned to their cages with suitable foods and water. On 13 days after surgery rats are anesthetized and wound area is evaluated. Wound sites are harvested using $6 \mathrm{~mm}$ punch biopsies over the central aspect of scar for biochemical analysis such as protein and mRNA extraction, and RNase protection assays for tumor necrosis factor [22].

\section{In vitro wound models}

In vitro models can generally be used as cell culture or organ culture [6]. The most investigated cells in wound healing research are fibroblasts, keratinocytes, macrophages, and epidermal or endothelial cells. Angiogenesis also studies using different in vitro models. The advantages of in vitro models in wound healing research are the direct examination of an environmental changes or substances or the tissue without influencing the other tissue components. The major disadvantages are the difficulty in extrapolating the results to fit the wounded tissue in an otherwise normal organism. In the cultures of cells activity observed by different collagen metabolites, amino acids, glycosaminoglycans, etc., following the modulation of cultures by cloning of cells or adding types of wound fluid or tissue factors. Organ culture of the skin can also 
be used. Following in vitro models are mainly used for wound healing study:

\section{Cell culture}

Fibroblast, keratinocytes, endothelial or epidermal cell culture can be used to understand the mechanism of growth proliferation, chemotaxis, cell attachment induction of various growth factors, cytokines, and many other genes responsible for the physiological actions. For these studies, some special in vitro wound model is used to study the effect of fibroblast on re-epithelialization in wounded human skin equivalents [23]. In these models cells are grown on silicon discs or on Petri dishes in monolayer and then cells from center are removed either cutting out disc or by means of a silicon rod. The migration of cells from periphery to center is observed. Using multicellular system such as co-culture and three dimensional for studies of cell-cell interaction and cell-matrix interaction, migration, proliferation, protein synthesis wound contraction, respectively. Organ cultures are also used for the study of epithelialization, tensile strength and morphology [6]

\section{Angiogenesis study}

Angiogenesis is a very important step in the wound healing. It is a process by which new blood vessels are generated through sprouting from existing blood vessels, begins outside the wound area causing the capillaries to move toward the wound site. After the injury, the end othelial cells at the boundary of the wound begin to regenerate forming a shell on the wound and the newly generated endothelial cells begin to migrate as long as good blood supply is available. The generation of new blood vessels within the wound area is stimulated and maintained as long as by certain growth factors such macrophage-derived growth factors, vascular endothelial growth factors, and TGF-b, these have the capacity to stimulate vessel growth and cologne deposition [24]. When the concentration of oxygen is low, macrophages appear at the wound site. These macrophages release chemical substances in the form of these growth factors. The newly formed capillaries transfer oxygen and vital nutrients to sell in the injured tissue, which are involved in the repairing process. Hence, sufficient blood supply and low level of oxygen within the wound space required for the successful wound healing process. The process of angiogenesis can be studied using following models:

\section{Chick CAM model}

This model is used to assess the angiogenic activity of an agent. 9-dayold fertilized chick eggs are selected and a small window (approximately $1.0 \mathrm{~cm}^{2}$ ) made in the shell. A small hole is drilled at the air space and air is sucked out using a rubber bulb, as a result of which the membrane fell. The window is open and a sterile disk of methylcellulose loaded with different amounts of test sample is placed in at the junction of two big vessels. The window is resealed by tape and the eggs are incubated at $37^{\circ} \mathrm{C}$ in a wall humidified chamber for 72 hrs after this duration eggs are opened and new vessel formation is observed and compared with that in eggs containing disks without drug sample [20].

\section{Tube formation on metrigel}

Angiogenesis is the formation of new capillaries, is critical for normal physiological process such as embryonic development and wound repair. However, it also facilitates pathological processes including tumor growth, metastases, proliferative diabetic retinopathy, and pannus formation in rheumatoid arthritis. The angiogenesis occurs through a series of events that include cell protease production, migration and proliferation, tubule formation and basement membrane incorporation. In vivo assay system, various kinds of growth factors are identified as angiogenic factors that promote endothelial cell proliferation and migration while an in vitro model for angiogenesis indicated that extracellular matrix (ECM) proteins stimulated endothelial cells to organize into a capillary-like tubular network and suggested that the ECM proteins are involved in the tubular formation process of angiogenesis [25]. In vitro studies of basement membrane degradation commonly employ endothelial cells cultured on a substrate designed to stimulate the extracellular matrix. The substrate include gels composed of collagen, fibrin or metrigel, a laminin-rich gel recently developed from reconstituted basement membrane proteins. These in vitro models involves endothelial cell attachments to the extracellular matrix, proteolytic invasion of the matrix in response to exogenous angiogenic inducers, endothelial cell alignment, and formation of capillary-like tubes [26]. In general, human umbilical vein endothelial cells (HUVEC) are used. When, HUVEC cells are plated on metrigel, a network of capillary-like structures capillary forms [27]. Attachment assay of cells are done by measuring average area per well of adherent cells in triplicate wells at $\times 25$ magnification with a computerized digital image analyzer connected to an Olympus microscope. For assay of tube formation first remove all medium by aspiration then culture is fixed and stained with Diff-Quik. The area of the tube network on the culture surface is quantified by suitable analyzer [28].

\section{Capillary growth in the mammalian cornea}

The angiogenic activity can be studied in the cornea of rabbits since this is an avascular A and transparent tissue where inflammatory reactions and growing capillaries can be easily monitored and changes quantified by stereomicroscopic examination [29].

\section{PARAMETERS USED TO ASSESS WOUND HEALING ACTIVITY}

Measurement of surface area and wound contraction

After wound creation from initial day to 2-3 days interval, the excise wound margin is traced at on transparent graph paper having a millimeter scale that is measured by a caliber with an accuracy of $1 / 20 \mathrm{~mm}$. Measurement is continued up to complete healing days. On each day the wound of the animals are photographically documented $[30,31]$. Wound contraction is expressed as percentage of wound area which is determined using following formula:

\section{$\%$ Wound contraction=Healing area '100/total area}

\section{Tensile strength}

Tensile strength is the resistance to breaking under tension. It indicates how much the repaired tissue resists to breaking under tension and may indicate in part the repaired tissue. For this the newly repaired tissue including scar is excised to measure the tensile strength. The instrument used for measurement is known as "Tensiometer" [30,31]. Tensiometer consists of a $6 \times 12$ inch wooden board with one arm of 4 inch log, fixed on each side of the possible longest distance of the board. The board is placed at the edge of a table; A pulley with wearing is mounted on the top of one arm. An alligator clamp with $1 \mathrm{~cm}$. Width is tied on the tip of another arm by a fishing line (20 lb test monofilament) in such a way that the clamp could reach of the board. Another alligator clamp is tied on a longer fishing line with $1 \mathrm{~L}$ polyethylene bottle on the other end.

\section{Measurement of tensile strength}

Before testing, the animals are anesthetized with ether in an open mask. One day before measurement of tensile strength, the sutures are removed from the stitched wounds of rats after recovery. The animal is then placed on a stack of paper towels on the middle of the board. The amount of the towels could be adjusted so that the wound is on the same level of the tips of the posts. The clamps are then carefully clamped on the skin of the opposite sides of the wound at a distance of $0.5 \mathrm{~cm}$ away from the wound. The longer piece of fishing line is placed on the pulley and the position of the board is adjusted so that the polyethylene bottle is freely hanging in the air, water is added to the polyethylene bottle at a rapid but constant rate by siphon from a large reservoir ( $20 \mathrm{~L}$ bottle) until the wound began to open up. The amount of water in the polyethylene bottle is weighed and considered to as the tensile strength of the wound. Two to three determinations are made on wounds on both sides of the animal are taken as the tensile strength of the wound. The tensile strength increment indicates better wound healing stimulation by the applied drug [32,33].

\section{Histological assessment}

Wound tissue specimens from treated and untreated rats are collected in $10 \%$ buffered formalin and after the usual processing $6 \mu \mathrm{mm}$ thick sections are cut and stained with HE $[34,35]$. Sections are qualitatively 
assessed under the light microscope and graded in respect of congestion, edema, infiltration of polymorph nuclear leukocytes and monocytes necrosis, fibroblast proliferation, collagen formation, angiogenesis and epithelialization.

\section{Assessment of biochemical parameters}

Deoxyribonucleic acid (DNA) and protein levels, used as markers of cell growth and are extracted and estimated in wound tissue. Other parameters hydroxyproline content, hexosamine content, hexuronic acid, lysyl A oxidase, collagenase, gelatinase assay, and urinary hydroxyproline assay also estimated [35]. Some of these parameters which are used frequently for wound healing study are discussed below:

\section{Determination of DNA}

A color reaction available for the determination and identification of DNA. The reaction with diphenylamine in a mixture of acetic acid and sulfuric acids at $100^{\circ} \mathrm{C}$ has been perhaps most widely used. However, the modified form of this reaction in which acetaldehyde is added to the reagents and by allowing the solution to stand for about $17 \mathrm{hrs}$ at $80^{\circ} \mathrm{C}$ instead of heating it at $100^{\circ} \mathrm{C}$. The modified method is 3.5 times sensitive as compare to original procedure and several substances which interfere in the original method do not do so in the modified procedure.

For the estimation of nucleic acid from biological materials, a suitable extract in $0.5 \mathrm{~N}-\mathrm{HClO}_{4}$ should be obtained. Then, the nucleic acid extract is diluted with $0.5 \mathrm{~N} \mathrm{HClO}_{4}$ so that the final solution contains between 0.02 and $0.25 \mu \mathrm{mg}$ atom of DNA $\mathrm{p} / \mathrm{ml}$ and measured volume $(1$ or $2 \mathrm{ml}$ as convenient) is mixed with 2 volume of diphenylamine reagent containing acetaldehyde. Tubes containing known amount of standard DNA and a blank containing $0.5 \mathrm{~N}-\mathrm{HClO}_{4}$ but no DNA are also prepared. The color is developed by incubating at $30^{\circ} \mathrm{C}$ for $16-20 \mathrm{hrs}$. It is known that all tubes are at the same temperature or constancy of temperature is not essential (variation 25-30). The optical density at $600 \mathrm{~mm}$ is measured against the blank and compared with the values obtained with the standard DNA [36].

\section{Protein measurement}

The measurement of protein with copper and the Folin reagent has certain advantages such as (i) It is sensitive as with Nessler's reagent, yet require no digestion, (ii) it is 10-20 times more sensitive than measurement of the ultraviolet (UV) absorption at $\lambda=280 \mathrm{~m} \mu \mathrm{m}$ and is much more specific and much less liable to disturbance by turbidities, (iii) it is several folds more sensitive than the ninhydrin reaction. Free amino acids give much more color than proteins with the ninhydrin reaction, whereas the reverse is true with the Folin reagent, and (iv) it is 100 times more sensitive than the biuret reaction.

The tissue lysate is treated with a mixture of sodium tartrate, copper sulfate, and sodium carbonate. This is left to stand for 10 minutes and then treated with Folin-Ciocalteu reagent that resulted in a bluish color in 20-30 minutes. The absorbance is measured in UV spectrophotometer at $650 \mathrm{~nm}$ [37]

\section{Hydroxyproline measurement}

The method of Woessner (1961) is used for determination of hydroxyproline in biological material containing as little as one part of hydroxyproline in 4000 parts of amino acids [38]. This method has been applied to a study of hydroxyproline distribution in cell particulates, tissue fluid, and purified animal proteins. Small sample of tissues protein is hydrolyzed without preliminary purification by adding HCL to a final concentration of $6 \mathrm{~N}$. The samples are sealed in small Pyrex test tubes and hydrolyzed for $3 \mathrm{hrs}$ at $130^{\circ} \mathrm{C}$. The tubes content is decanted into a graduate cylinder or volumetric flask. Several drops of $0.02 \%$ methyl red indicator are added, followed by the addition of $2.5 \mathrm{~N} \mathrm{NaOH}$ required for neutralization. A final adjustment is made with dilute HCL and $\mathrm{NaOH}$ until the indicator turns slightly yellow corresponding to $\mathrm{pH}$ 6-7. Hydroxyproline oxidation is initiated by adding $1 \mathrm{ml}$ chloramine-T to each tube in a predetermined sequence. The tube contents are mixed by shaking a few times and allowed to stand for 20 minutes at room temperature. The chloramine-T is then destroyed by adding $1 \mathrm{ml}$ of perchloric acid to each tube in the same order as before. The contents are mixed and allowed to stands for 5 minutes. Finally, $1 \mathrm{ml}$ of p-dimethylaminobenzaldehyde solution is added, and the mixture is shaken until no schlieren can be seen. The tubes are placed in $60^{\circ} \mathrm{C}$ water bath for 20 minutes then cooled in tap water for 5 minutes. The developed color is stable for at least $1 \mathrm{hr}$. The absorbance of the solution is determined using UV-visible spectrophotometer at $557 \mathrm{~nm}$. The hydroxyproline content is determined directly from the standard curve.

\section{Extraction and estimation of lysyl oxidase from granuloma tissue} The sample of granuloma tissue is prepared by homogenizing the tissue in a mortar with pestle, using $0.02 \mathrm{M}$ potassium phosphate buffer, $\mathrm{pH}$ 8.2. This is stirred for 20 minutes and cold centrifuged. The supernatant served as a source of lysyl oxidase. Lysyl oxidase activity is assayed spectro-fluorometrically, using a monoamine substrate and an adaptation of the peroxidase coupled assay [39-41]. The assay system contained $250 \mu \mathrm{g}$ of sodium homovanillate, $40 \mu \mathrm{g}$ of horseradish peroxidase, $100 \mu$ moles of $0.01 \mathrm{M}$ butyl amine substrate in a final volume of $3 \mathrm{ml}$. The reaction is started by the addition of lysyl oxidase. All the tubes are incubated at $37^{\circ} \mathrm{C}$ for 30 minutes, and the reaction stopped by placing the tubes in ice. Fluorescence measurements are made at $420 \mathrm{~nm}$ with excitation at $320 \mathrm{~nm}$. Lysyl oxidase activity is expressed as units/g tissue protein.

\section{SUMMARY AND CONCLUSION}

The wound healing process consists of four highly integrated and overlapping phases: Hemostasis, inflammation, proliferation, and tissue remodeling. These phases and their biophysiological functions must occur in the proper sequence, at a specific time and continue for a specific duration at an optimal intensity. There are many factors that can affect wound healing which interferes with one or more phases in this process, thus causing improper or impaired tissue repair.

Laboratory investigations and clinical studies have yielded a wealth of information about both normal and impaired wound healing. More recently, a great deal of research has been directed at understanding the critical factors that influence poorly healing wounds. While much remains to be learned, these studies may lead to therapeutics that will promote proper tissue repair and improve impaired wound healing. Research on wound healing drugs is a developing area in modern biomedical sciences. Scientists who are trying to develop newer drugs from natural resources are looking toward the Ayurveda, the Indian traditional system of medicine.

In vivo wound models can offer reliable and reproducible information on the performance and response of wound to experimental healing. The researcher must consider the merits and demerits of each type of wound model. Impaired healing is comparatively to easily created, but the actual chronic wound that is an important clinical target, which is rarely attained in laboratory experimental animals. The developed wound models should attempt for reproducibility, similar to humane treatment, clinical relevance, and quantitative elucidation. In general, study on animal models considered approximate similar to human wound healing studies and it is better than in vitro studies. Although the animal selection can be difficult since its ability to model human wound healing. In addition, small mammals are inexpensive, easy to handle and maintain, can be genetically modified. Swine are more expensive and difficult to handle, but their anatomical and physiological similarities to humans make them a choice of model. Although in vitro and in vivo models have several unique advantages and disadvantages, but no one model is capable of completely representing human wound healing. In vitro assays and animal models are moving stones to well-controlled clinical trials.

\section{REFERENCES}

1. Mast BA. The Skin. In: Cohen IK, Diegelmann RF, Linblade WJ, editors. Wound Healing Biochemical and Chemical Aspects. Philadelphia, PA: WB Saunders Company; 1992. p. 344-55. 
2. Yardley PA. A Brief History of Wound Healing. Oxford: Clinical Communication Inc.; 1998.

3. Shukla A, Patnaik GK. Wound healing: Molecular mechanism. Proc Nat Acad Sci India 1998;LXVIII:1-13.

4. Charde MS, Fulzele SV, Satturwar PM, Dork AK. Wound healing activity of Durva ghrita. Indian J Pharm Sci 2003;65(5):482-5.

5. Mukherjee PK. Quality Control of Herbal Drugs. $1^{\text {st }}$ ed. New Delhi: Business Horizons; 2002. p. 546-8.

6. Gottrup F. Experimental wound healing research: The use of model. EWMA J 2001;1(2):5-8

7. Tortora GJ, Grabowski SR. Principle of Anatomy and Physiology. $7^{\text {th }}$ ed. New York: Harper Collins College Publishers; 1993. p. 135-7.

8. Clark RA, editor. Wound repair: Overview and general considerations. In: The Molecular and Cellular Biology of Wound Repair. New York: Plenum; 1996. p. 3-50.

9. DiPietro LA, Burns AL. Wound Healing: Methods and Protocols. Totowa, NJ, USA: Humana Press, Inc.; 2003.

10. Jeffery MD. Experimental animal models. Wounds 2001;13(1):9-23

11. Hemalata S, Subramanian N, Ravichandran V, Chinnaswamy K. Wound healing activity of Indigofera ennaphylla Linn. Indian J. Pharm Sci 2001;63(4):331-3.

12. Taranalli AD, Tipare SV, Kumar S, Torgal SS. Wound healing activity of Oxalis corniculata whole plant extract in rats. Indian J Pharm Sci 2004;66(4):444-6

13. Shirwaikar A, Shenoy R, Udupa AL, Shetty S. Wound healing property of ethanolic extract of leaves of Hyptis suaveolens with supportive role of antioxidant enzymes. Indian J Exp Biol 2003;41:238-41.

14. Patil MB, Jalalpure JS, Ashraf A. Preliminary phytochemical investigation and wound healing activity of the leaves of Argemone maxicana Linn. (Papaveraceae). Indian Drugs 2001;36(6):288-93.

15. Sultana Y, Aquil M, Ali A. Burn and its management. Humdard Med 2004;54(1):66-71

16. Knabl JS, Bayer GS, Bauer WA, Schwendenwein I, Dado PF, Kucher C, et al. Controlled partial skin thickness burn: An animal model for studies of burn wound progression. Burn 1999;25:229-35

17. Walker HL, Mason AD. A standard animal burn. J Trauma 1968:8:1049-51.

18. Yalcin O, Soybir G, Koksoy F, Kose H, Ozturk R, Cokneseli B. Effect of granulocyte colony stimulating factor on bacterial translocation due to burn wound sepsis. Surg Today 1997;27:154-8

19. Nakae H, Inaba H. Effectiveness of electrolyzed oxidized water irrigation in a burn-wound infection model. J Trauma 2000;49(3):511-4.

20. Bairy KL, Abhinav R, Satyam SM. Evaluation of burn wound healing activity of topical regular insulin in non-diabetic and streptozocininduced diabetic rats. Int J Pharm Pharm Sci 2014;6(8):127-30.

21. Chin G, Gowda S, Schultz G. Evaluation of platelet-derived growth factor in a rat model of ischemic skin wound healing. Wounds 2002;14(5):199-203.

22. Blalock EM, Chen KC, Vanaman TC, Landfield PW, Slevin JT. Epilepsy-induced decrease of L-type $\mathrm{Ca} 2+$ channel activity and coordinate regulation of subunit mRNA in single neurons of rat hippocampal 'zipper' slices. Epilepsy Res 2001;43:211-6.
23. Ghalbzouri AE, Hensbergen P, Gibbs S, Kempenaar J, Schors R, Ponec M. Fibroblasts facilitate re-epithelization in wounded human skin equivalents. Lab Invest 2004;84:102-12.

24. Maggelakis SA. Modeling the role of angiogenesis in epidermal wound healing. Discrete Continuous Dyn Syst Seri B 2004;4(1):267-73.

25. Imamura M. Extracellular matrix components and angiogenesis. Nippon Yakurigaku Zasshi 1996;107(3):153-60.

26. Goldenberg NA. Elucidating angiogenesis: The role of basement membrane proteolysis and endothelial cell motility and proliferation. MJM 1995;1:127-37.

27. Maheshwari RK, Srikantan V, Bharitiya D, Kleinman HK, Grant DS. Differential effect of interferon gamma and alpha on in-vitro model of angiogenesis. J Cell Physiol 1991;146(1):164-9.

28. Marales DE, McGowan KA, Grant DS, Maheshwari S, Bhartiya D, Cid $\mathrm{MC}$, et al. Estrogen promotes angiogenesis activity in human vein endothelial cell in-vitro and in a murine model. Circulation 1995;91:755-63

29. Kilarski WW, Samolov B, Petersson L, Kvanta A, Gerwins P. Biomechanical regulation of blood vessel growth during tissue vascularization. Nat Med 2009;15(6):657-64.

30. Hirapara HN, Ghori VM, Anovadiya AP, Tripathi CB. Effect of amlodipine and enalapril on wound healing in diabetic Wistar albino rats. Int J Pharm Pharm Sci 2016;8(7):257-61.

31. Shukla R, Rai G, Jain AP. Preclinical evaluation of Alpinia galanga rhizomes for wound healing activity with reducing oxidative status. Asian J Pharm Pharmacol 2015;1(2):65-9.

32. Saha K, Mukherjee PK, Das J, Pal M, Saha BP. Wound healing activity of Leucas lavandulaefolia Rees. J Ethanopharmacol 1997;56:139-44.

33. Singh S, More PK, Shukla R. Ameliorative effect of flavonoids rich extract from Plantago lanceolata for cutaneous wound healing with antioxidant mechanism. Adv Pharm J 2016;1(1):21-5.

34. MCmanus JF, Mowry RW. Staining methods, histologic and histochemical. New York, Evanston, London: Harper and Row; 1965.

35. Udupa SL. Inhibition of lysyl oxidase by isoniazid and its effect on wound healing. Indian J Exp Biol 1995;33:278-80.

36. Burton K. A study of the condition and mechanism of the diphenylamine reaction for the colorimetric estimation of deoxyribonucleic acid. Biochem J 1956;62:315-21.

37. Lowry OH, Rosebrough NJ, Farr AL, Randall RJ. Protein measurement with the folin phenol reagent. J Biol Chem 1951;193:265-75.

38. Woessner JF. The determination of hydroxyproline in tissue and protein samples containing small portion of this imino acid. Arch Biochem Biophys 1961:193:440-7.

39. Chithra P, Sajithlal GB, Chandrakasan G. Influence of Aloe vera on collagen turnover in healing of dermal wounds in rats. Indian J Exp Biol 1998;36:896-901.

40. Synder SH, Hendley ED. In: Tabor H, Tabor CW, editors. Methods in Enzymology. Vol. 17B. New York: Academic Press; 1971. p. 741.

41. Trackman PC, Kagan HM. Nonpeptidyl amine inhibitors are substrates of lysyl oxidase. J Biol Chem 1979;254(16):7831-6. 